\title{
Learning Resource Services in the Community College: On the Road to the Emerald City
} W. Lee Hisle

This article discusses the community college environment in which learning resource services (LRS) programs exist. The history and growth of LRS programs are summarized and five major challenges for the future are outlined: focus, instructional involvement, adapting to technology, service to nontraditional students, and professional commitment and liaison. It is suggested that, even though the LRS program concept is widely accepted, these challenges must be met if academic excellence in LRS programs is to be achieved.

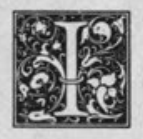

n 1939, Hitler invaded Poland. Sigmund Freud died in London at the age of 83. Albert Einstein wrote to President Roosevelt informing him that an atomic bomb was feasible. And MGM released The Wizard of $\mathrm{Oz}$, a movie about a girl and her dog who, buffeted by the winds of change, discover they aren't in Kansas anymore. In the same year that Dorothy and Toto traversed the yellow brick road in search of one who could make their wishes come true, the Association of College and Research Libraries (ACRL) was formed. During the ensuing fifty years, academic libraries have helped millions of Americans make their wishes for knowledge and academic achievement come true. One segment of academic libraries, the community college learning resource services (LRS) program, has come of age and now serves more undergraduate students than any other single segment of American higher education. ${ }^{1}$ LRS programs are still following that mythical highway of yellow brick, and though many adventures lie ahead, Oz is much closer today than it was fifty years ago.

The past, present, and future of community college LRS programs correspond to the development of their parent institutions. Community colleges began in the early 1900 s, yet they face serious questions about their direction and mission in today's educational environment. During the 1960 s and 1970s, they came through a time of tremendous growth and change; now they are being challenged to develop a cohesive presence to deal with educational problems in our society. The decade of the eighties has been called the turning point for American community colleges by some, while others have suggested that community colleges are in a "mid-life crisis" and are searching for new meaning. ${ }^{2}$ As community college leaders question assumptions held from the early days, they are redefining the role and function

W. Lee Hisle is Director of Learning Resource Services, Austin Community College District, Austin, Texas 78714. 
of these colleges in the higher educational environment.

Community college LRS programs, reflecting their college environment, are in a similar state of redefinition. The too have had to deal with tremendous growth and change. They too are faced with questions regarding their role and function. While there is no longer a question in community college circles of the validity of the LRS concept, which combines library with media and often other educational support services, LRS programs face many problems in building a cohesive approach to service. (Even the name, learning resource services, is not standard, although for the purposes of this paper, LRS will encompass all variations.) Fortunately, as with any redefinition, LRS programs have the opportunity to become stronger, more adaptable, and better able to assist in achieving the community college mission.

\section{THE COMMUNITY COLLEGE ENVIRONMENT \\ Background}

To understand the problems, trends, and opportunities facing community college LRS programs, it is necessary to understand the context in which they have developed and in which they exist. Although community colleges began in 1896 at the University of Chicago, in the elitist vision of William Rainey Harper, who wanted to separate lower- from upperdivision students, the movement owes its strength to the American sense of democracy. As George Vaughan points out, Thomas Jefferson called for the establishment of a college within a day's travel for all Virginians. Jefferson believed that talent and intelligence knew no social or economic barriers and even called for occupational training, along with courses for

\footnotetext{
"The Morrill Acts of $\mathbf{1 8 6 2}$ and $\mathbf{1 8 9 0}$ established the land grant colleges and began a federally supported effort to educate working people without the barrier of restrictive admissions."
}

avocational pursuits, to be taught in the evening when working people could attend. $^{3}$

The Morrill Acts of 1862 and 1890 established the land grant colleges and began a federally supported effort to educate working people without the barrier of restrictive admissions. For the first time, agricultural and mechanical courses were taught in a higher education sphere. They were even called "people's colleges," foreshadowing the role of community colleges in providing education to all citizens. ${ }^{4}$ The land grant colleges also pioneered the idea of communitywide service through their agricultural and general education extension programs. Access to education through extension programs increased enrollments and eventually led to the establishment of curricula reflective of vocations such as business management and journalism. Greater variety in programming led to increased diversity in student demographics, which led again to newer programs. ${ }^{5}$

In 1921, the American Association of Junior Colleges, later called the American Association of Community and Junior Colleges (AACJC), was founded to promote the community college movement. ${ }^{6}$ As early as 1936, A.D. Hollingshead suggested that junior colleges become more community oriented by providing programming designed to satisfy community needs: adult education offerings and recreational/vocational programs. ${ }^{7}$ By the end of World War II, these colleges were ready to integrate into the practices of higher education the democratic ideals for which the nation had fought. ${ }^{8}$

Two events in the late 1940 s set the stage for the unprecedented surge in community college enrollments and the establishment of a permanent place for community colleges in the higher education landscape. In 1944, Congress passed the G.I. Bill of Rights, which provided to veterans the financial support needed for college expenses and, for all practical purposes, made their education seem an entitlement. ${ }^{9}$ Three years later, the 1947 President's Commission on Higher Education for American Democracy, known as the Truman Commission, strengthened the 
future of community colleges when it called for open access to education two years beyond high school. This would be accomplished through locally controlled, commuting-distance institutions called community colleges. ${ }^{10}$ The commission suggested that the role of community colleges should be the provision of education for all the citizens of the community regardless of race, sex, religion, color, geographic location, or financial status. ${ }^{11}$

Although community colleges grew in part from the demand for trained workers for the nation's postwar industrial plants, another significant factor was the drive for social equality. ${ }^{12}$ This drive complemented the expanding community college movement. Supported by the increase in fifteen- to twenty-four-year-olds, up by 68 percent between 1955 and 1970, community colleges became known for equal and open access. ${ }^{13}$ Many students, regardless of their academic backgrounds, came to view community college education as a basic right, not necessarily an earned privilege. Today, community colleges enroll approximately 43 percent of all undergraduates and 51 percent of all first-time entering freshmen, forming the largest single sector of higher education in the United States. ${ }^{14}$ They have been phenomenally successful at attracting students and gaining a central place in the American higher educational environment.

\section{Problems}

Success, however, has lead to problems. Although community colleges have sought excellence through providing open admissions to all students, open access with academic excellence has been a goal rarely achieved. For example, open access enrollments bring students who are unable to read, write, or compute on a basic level-a group now becoming a majority in some colleges. The open door for these students can become a revolving door, ushering students out as fast as they enter unless a different, more responsive curriculum, along with other intervention strategies, are provided. ${ }^{15}$ The time, energy, money, and leadership needed to establish these strategies are often lacking. The conflict between the democratic

\begin{abstract}
"The open door . . . can become a revolving door, ushering students out as fast as they enter unless a different, more responsive curriculum, along with other intervention strategies, are provided."
\end{abstract}

ideal of open access and the societal pressure for standards is thus intrinsic to the modern community college.

The overlap of transfer and technical courses has added to the complexity of understanding community college education. Other problems include accommodating the return to college of single parents, women who desire to reenter the work force, older students, and other nontraditional students outside the mold of the eighteen- to twenty-two-year-old stereotype. ${ }^{16}$ These students are typically, in the words of Edmund Gleazer, "ambitious toward ends but uncertain of the means by which desirable but vague objectives can be achieved." ${ }^{17}$ (As Barbara Moran points out, these enrollment trends are not totally unique to community colleges. However, community colleges enroll a greater percentage of these students than do other segments of higher education. ${ }^{18}$ Leveling enrollments and increasing fiscal restraints, both internally imposed and forced on colleges by governing boards and legislatures, have increased the tension between dedication to a mission and the constraints of limited financial resources. ${ }^{19}$ New technology and its ability to deliver instruction and communicate information to distant locations permit new approaches to curriculum development. Inclusion of new technology in instruction requires a reconsideration of budgetary priorities as well. Gloria Terwilliger points out that "the adoption of large-scale high technology is straining the financial resources of our colleges and drawing funds away from existing instructional supports and technologies."

All of these factors add to the difficulty community colleges have had establishing a distant, focused, institutional purpose 
and organizational identity. As Arthur Cohen and Florence Brawer assert, "Community colleges do not even follow their own traditions." 21

\section{New Direction}

Over the last few years, a significant new direction has begun to emerge for community colleges. In 1986, the board of directors of the AACJC appointed the Commission on the Future of the Community College. The commission's report, published in 1988, is entitled Building Communities: A Vision for a New Century. It signals a refocused, invigorated approach to the mission of the community college. The report says:

At their best, community colleges recognize and enhance the dignity and power of individuals. Students come to colleges to pursue their own goals, follow their own aptitudes, become productive, self-reliant human beings, and, with new knowledge, increase their capacity and urge to continue learning. Serving individual interests must remain a top priority of community colleges. But they can do much more. By offering quality education to all ages and social groups, community colleges can strengthen common goals as individuals are encouraged to see beyond private interests and place their own lives in larger context. Community colleges, through the building of educational and civic relationships, can help both their neighborhoods and the nation become selfrenewing. ${ }^{22}$

The report calls for "building communities" to become rallying points for all community colleges. It stresses, however, that outreach is not enough; rather, partnerships based upon shared values and common goals are essential. How are partnerships formed? Through excellence in teaching, for "at the center of building community there is teaching. Teaching is the heartbeat of the educational enterprise and, when it is successful, energy is pumped into the community, continuously renewing and revitalizing the institution." ${ }^{\prime 23}$

The essential challenge of LRS programs in community colleges is to participate and contribute to this new vision of the community college mission. Excellence in teaching must be a metaphor for excellence in reference services, for excel- lence in media production, for excellence in bibliographic instruction, collection development, and individualized instruction, and for the host of other activities that a LRS program contributes to its college environment. Partnerships must be formed with excellent teachers and administrators to provide leadership for the next fifty years.

\section{DEVELOPMENT OF COMMUNITY COLLEGE LEARNING RESOURCE SERVICES \\ History of Neglect}

As they matured more slowly than did the colleges themselves, excellence has rarely been a hallmark of community college LRS programs. In 1939, when the ACRL was founded, most community college libraries were only beginning to develop. ${ }^{24}$ Collections were small and other resources were scarce. Responsiveness to institutional needs was a goal, but one that was difficult to accomplish and in little evidence.

Mary Alice Webb recounts the history of neglect suffered by community college library programs from their inception until the mid-sixties. ${ }^{25}$ Joleen Bock substantiates this history while pointing out the few bright spots that were evident, including the work of B. Lamar Johnson. This early leader in the community college movement began as the librarian of Stephens College in Missouri (which was at the time a junior college). Johnson later developed the Community College Leadership Program at UCLA and founded the League for Innovation in the Community College. Propitiously, his seminal book, Vitalizing a College Library, was published in 1939. In it he called for community college libraries to become curriculum leaders with campuswide instructional responsibilities. ${ }^{26}$ Johnson's efforts at creating mutually supportive relationships between the library and the classroom and his call to treat similarly all types of communications materials foreshadowed the development of the LRS concept in the $1960 \mathrm{~s}^{27}$

\section{Turnaround}

During the sixties, library leaders in 


\section{"During the sixties, library leaders in community colleges began moving their libraries from being merely re- positories of materials toward be- coming increasingly involved in their college's instructional pro- grams."}

community colleges began moving their libraries from being merely repositories of materials toward becoming increasingly involved in their college's instructional programs. Armed with the 1960 Standards for Junior College Libraries, ${ }^{28}$ librarians " attempted to mold community college libraries into agencies of sufficient strength to meet the varieties of need in the community college. ${ }^{\prime 29}$ This effort was valiant but needed the impetus of three significant events during the late 1960 s and early 1970 s to propel community college libraries into a position of strength from which they could offer adequate service and develop into the often exemplary support programs they are today.

The 1960 Standards did not compel colleges to strengthen their library programs sufficiently. Indeed, some community college presidents were angered by the seemingly arbitrary recommendation about collection size. The stage was set for the first major event that began the turnaround toward excellence. In 1966, E. J. Gleazer, then the executive director of the American Association of Junior Colleges, wrote a pivotal article for College \& Research $\mathrm{Li}$ braries, entitled "The Stake of the Junior College in Its Library. ${ }^{\prime 30}$ Gleazer, writing that " of all aspects of junior college development, less attention has been given to the junior college library than to any other part of the instructional program," heralded an awakened concern for the state of the library program in community colleges. ${ }^{31}$ Gleazer's reputation and position in the community college profession encouraged community college leaders, perhaps for the first time, to consider seriously the inadequacy of their colleges' library programs. His leadership in this area should not be underestimated.
Gleazer called for the development of "guidelines to encourage and support effective library services both for new and existing institutions. ${ }^{\prime \prime 32}$ He went on to say,

It is not enough to borrow the patterns and forms and procedures which may have worked well for other kinds of educational institutions with other assignments and missions. It may be a dangerous fallacy to assume that these will fit the role of the community college. They may or they may not. What is needed is an honest analytical examination of the kinds of library services required to give expression to the community college concept. ${ }^{33}$

Gleazer's words could not have better reflected the redefinition then occurring in community college libraries. The influx of audiovisual materials and attendant technology found community college libraries expanding their role as these new types of materials and technology were woven into a program of service. Thus, the second major event to improve community college libraries, indeed to change them forever, was really more of a movement: the quickening shift toward a learning resources concept of service. The LRS embodied an organizational structure that included not only traditional library service but also audiovisual services, including instructional development and media production.

The LRS concept may have begun as early as 1928 when the Carnegie Corporation assisted colleges in acquiring phonograph records. The concept gained credibility when the first audiovisual course was offered by Louis Shores at George Peabody College in 1935 . The idea of the "library-college," also developed in the 1930 s by Shores, helped mold LRS philosophy. ${ }^{34}$ In 1939 , the same year that the ACRL was founded, B. Lamar Johnson gave significant support to the idea. ${ }^{35}$ Bock reports that the term learning resource center was first used officially at a 1967 conference entitled Junior College Libraries: Development, Needs, and Perspectives sponsored by ALA, American Association of Junior Colleges, and the University of California at Los Angeles. (B. Lamar Johnson was at UCLA by this time.) Representatives from Monroe Community College in Michigan and the Dallas County 
Community College District used the learning resources terminology to describe their evolving library programs. They called for libraries to become learning resource centers by embracing a concept of service in which libraries are not just for books but for all types of media. The interrelationship between LRS and the college instructional program was also emphasized. ${ }^{36}$

The concept of LRS gained attention in the late 1960 s through the mid-1970s as new community colleges were being founded at an extraordinary rate and the LRS philosophy was instituted in a college at its founding. A broad range of services became the norm rather than the exception and included, among others, library services, audiovisual materials collection, audiovisual equipment distribution, graphic and photographic reproduction, video production, audio- and videolearning laboratories, tutorial services, reprography, career information centers, and learning assistance centers. ${ }^{37}$

Ruth Person points out that the community college library embraced the LRS concept due to

... the pattern of initiation of services, experimentation, rapid change, tremendous growth, and struggle with challenges [which] characterized the two-year college and its library. The need to provide learning and informational materials to an enormous variety of students, combined with the lack of commercially-available materials to address different learning styles, educational needs and new subject areas placed a great burden on learning resources programs. $^{38}$

The movement toward the learning resources concept remains strong, although questions are arising regarding the optimal size and characteristics of LRS programs. Some indviduals question whether LRS programs will or should expand beyond library and audiovisual services to incorporate such ancillary support services as microcomputer labs and college printing services. ${ }^{39}$ Such debate is essential as LRS programs mature and helps keep the LRS concept vibrant and healthy.

In 1972, the third major event in the development of community college libraries took place. Solidifying the LRS concept and satisfying some of the needs that Gleazer enumerated in 1966, the adoption of the 1972 Guidelines for Two-Year College Learning Resources Programs ${ }^{40}$ was an important step in the progress of community college libraries. The Guidelines reflected a change in philosophy for library programs, including provisions for the integration of library and audiovisual services, the inclusion of production in these services, and the involvement of learning resources in instruction. In addition, use of the term learning resources in the title of the Guidelines, reflecting the broad acceptance of the LRS concept in community colleges, indicated the growth and maturity of the service. ${ }^{41}$ Since the publication of the 1972 Guidelines, it has been less and less appropriate to speak of community college libraries. Most colleges and researchers in the field accept and use the LRS terminology or some similar variation. Today, in most community colleges the term library has become at the least a misnomer, if not altogether anachronistic.

Even with the importance of the title change, the 1972 Guidelines were most significant because for the first time standards were adopted simultaneously by the three national organizations most important to community college libraries: the ACRL, a division of the ALA; the Association for Educational Communications and Technology (AECT); and the AACJC. ${ }^{42}$ The 1972 Guidelines had considerably more influence on community college operations than earlier efforts and are in large part responsible for the success of community college LRS programs developed since their publication. The 1972 Guidelines were later supplemented by quantitative standards in 1979 and were revised slightly in 1982, but the essential concepts and philosophy remain unchanged. $^{43}$

\section{New Standards}

Of course, the 1972 Guidelines could not meet the needs of the profession indefinitely. The authors recognized that their work would require significant upward revision when community colleges and LRS programs reached new stages in their development. Greater numbers of re- 
sources and greatly extended services would demand future revision. To accommodate the changes in LRS programs and community colleges over the past twenty years, new standards have been developed recently by a joint committee of the ACRL and AECT. Published in draft form in 1989, formal ACRL/AECT adoption should come in $1990 .^{44}$

The new standards will once again assert the importance of the learning resources concept, but with new emphasis on microcomputer and telecommunications technology. Among the changes will be the integration of (revised) quantitative figures into the textual discussion of qualitative standards. A significant, though symbolic, difference is that the term twoyear college in the title will be replaced with community, technical, and junior college, reflecting the changing nature of student enrollment patterns in community colleges (i.e., rarely does a student spend two years in a community college). Also, among the many changes in quantitative measures, the new standards will call for a much more realistic LRS percentage of a college's educational and general expenditure budget. Unfortunately, the AACJC has not been involved in a formal way with the development of the new standards as they were in 1972 . This is likely to have a negative effect on college adoption of the new standards unless some form of support can be obtained from the AACJC. It is hoped that the inclusion of the term learning resources in the title, as was done in 1972, will encourage all community colleges to adopt this designation. Consistent use of the term in all areas of the country is necessary if administrators and others are to understand and accept LRS programs as an integral unit within a college.

\section{WHAT OF THE FUTURE?}

Peter Drucker argues that the most important time to ask "what is our business?" is when an organization has been successful. ${ }^{45}$ The development of the learning resources concept over the past fifty years is evidence of LRS success and maturity. But there is another question Drucker insists be answered as well: "what will our business be?" The changes in the higher education environment will have an impact on the future characteristics, mission, and purpose of learning resources. Thus it is necessary to ask "what will we be?" to plan effectively for present and future services. ${ }^{46}$

As community colleges are faced with new demands and considerations in defining their role and mission, LRS programs, the instructional resources support services in a college, are faced with questions about their role in a changing environment. Moran's comments about academic libraries are relevant here:

Today's academic libraries are facing a series of challenges that arise from factors both internal and external to the library itself. As libraries, the primary information resources on campuses, enter the so-called "information age," they face a number of common problems. Libraries' [read Learning Resource Services'] responses to these challenges will determine the shape of the academic library of the future. ${ }^{47}$

Moran goes on to say that there is little group consensus on appropriate responses. LRS professionals may be viewing changes in a "dangerously passive manner-expecting new roles.... will evolve and that the changes taking place will be evolutionary rather than revolutionary. ${ }^{\prime 48}$

The development of the LRS has in part resulted from a collaborative relationship between instructional faculty and LRS staff. Instructional problems and their solutions have been a shared responsibility. However, Terwilliger reports that these relationships are breaking down as new technology requires new ways of delivering instruction. ${ }^{49}$ Carl Cottingham echoes her concerns, saying that new strategies and methods of teaching resulting from adoption of new technology have changed the ways learning resources are operating. ${ }^{50}$ If old relationships are breaking down and new strategies are forcing redefinition, what will be the new roles of LRS programs in this changing environment? More importantly, what are the strategic issues facing community college LRS programs which will define these new relationships and roles? 


\section{FIVE ISSUES FOR THE FUTURE}

The past, present, and future in academic libraries were ably discussed by Moran in an earlier fiftieth anniversary feature. ${ }^{51}$ Her research and insight are by and large applicable to the library aspect of community college LRS programs. I commend her excellent work to the reader. She, and others, have rightly pointed out that the difference between now and the future will likely be one of degree. With growth as the keyword, the problems that have beset us in the past will only loom larger in the future. Problems will not dissolve into some mist of new technological wonderment. Rather, we will struggle with many of the same weaknesses with which we tussle today. As Jonathan Fanton, president of the New School for Social Research, says,

The advent of a new century does not imply a radical change, a sharp break with the past. Rather, it signals an intensification of the dilemmas we now face and an ever-mounting set of challenges, albeit ones that not are easily foreseen. $^{52}$

Looking at the community college LRS environment, however, there are five critical issues, five challenges, which must be faced if excellence is to be achieved. Not necessarily new, these issues nevertheless focus on what we must do-those areas of greatest importance-to provide LRS programs with a future as distinguished as its past.

\section{Focus}

The concept of LRS was clearly defined in the 1960 s and 1970s when audiovisual services were added to library programs. Now, there is less consensus as to what an LRS program should encompass. For example, Terwilliger argues forcefully that microcomputing labs should be organized as part of LRS programs. ${ }^{53}$ Whether this new role will be a part of the LRS of the future is, however, undecided. Peggy Holleman's research indicates there is disagreement over which additional services are appropriate to LRS programs. ${ }^{54} \mathrm{My}$ research, completed in 1988, indicates that LRS roles are clearly defined and accepted only for traditional library and audiovisual
"Both the 1972 Guidelines and the draft 1989 Standards encourage a situational definition for LRS programs by accepting whatever is occurring at the local level as appropriate, so long as library and audiovisual services are represented."

services. Whether it is appropriate to include emerging areas such as telecommunications and microcomputer support into LRS programs is much less agreed upon, not only by LRS directors/deans, but also by presidents and vice-presidents of community colleges. ${ }^{55}$

Adding to the confusion, both the 1972 Guidelines and the draft 1989 Standards encourage a situational definition for LRS programs by accepting whatever is occurring at the local level as appropriate, so long as library and audiovisual services are represented. ${ }^{56,57}$ Over thirty roles are identified as possible LRS functions in the 1989 Standards, including college catalog production, college press, copy shop, public museum, and telecourse administration. ${ }^{58}$ The traditional LRS program, just as was observed about community colleges, seems to be one which has no traditions.

While local autonomy is desired, it is also important to have a degree of standardization in LRS programs. A clearer and more consistent definition will facilitate program comparison, foster better training programs for LRS professionals, and make easier the task of explaining to administrators, accrediting bodies, associated professional organizations, and legislative overseers what the LRS program does. Too many areas under the LRS umbrella may also reduce the focus on the cornerstones of the LRS program-library and audiovisual services. A consistent LRS mission would heighten the perceived and real importance of the LRS concept in the educational community.

\section{Instructional Involvement}

The key to the future success of any LRS program is the degree to which it is inte- 
grally involved with the instructional program of its college. No more central issue exists, although sometimes this basic fact is overlooked as technological and administrative demands cloud our vision. Currently, there is evidence that instructional involvement is not seen as a critical need by LRS directors. ${ }^{59}$ Other research indicates that a paltry 38 percent of community college instructors use library resources in their instruction. ${ }^{60}$ John Lanning, though speaking from the standpoint of a university environment, makes arguments that are applicable to community colleges. He states that the current relationship between faculty and librarians is "distant, ineffective, and often driven by frustration. ${ }^{\prime \prime 1}$ Role separation between teaching faculty and librarians can impede progress and, as Donald Ray says, "Political divisions-librarians do this, teachers do that-hobble the library in the most fundamental way., ${ }^{\prime 62}$

The most important way to achieve integration is through developing partnerships with teaching faculty and fostering a well-developed and heavily supported program of bibliographic instruction or, as it is often called in community colleges, library use instruction (LUI). LUI, integrated into the curriculum, can foster librarian/teacher partnerships in the instructional program of the college. ${ }^{63}$ LUI must be taught as a means and not as an end unto itself. LUI that offers "predigested information to be retrieved by prearranged procedures" is of little service to students who need skills for lifelong learning. ${ }^{64}$ Community college students in particular need a LUI program that incorporates the open-ended characteristics of the library's knowledge base in that it reflects real-world learning as distinct from classes, which may reduce learning to the assimilation of discrete bits of information. ${ }^{65}$

An LRS partnership with teaching encourages faculty to look toward the LRS for help in developing new teaching methods and materials and for assistance on curriculum development. With knowledge of collection strengths and the range of services available from the LRS, librarians and other LRS staff must seek to serve on curriculum development committees as LRS advocates. As Mary Sue Ferrell, a former community college LRS director and now executive director of the California Library Association, says, "The teaching-learning process is the heart of the institution and the role of the library is to enhance this process by forming partnerships with faculty. " 66

\section{Adapting to Technology}

Technology will remain a force within LRS environments for the foreseeable future. In many colleges, the use of technology to assist with the work of the LRS is commonly accepted and survival without its help is unthinkable. Advances in technology will continue and greater benefits from its use will be available. Even though, as Moran says, "The biggest unanswered questions related to the future of higher education is what impact the electronic information technologies will have on this nation's colleges and universities," it is the responsibility of LRS program staff to keep abreast of new developments, using technology to serve students, faculty, and staff effectively. ${ }^{67}$ The LRS program should also provide technological leadership to other areas of the college. Telefacsimile systems, electronic mail, and various forms of telecommunications should be familiar to LRS staff and be developed for other college departments.

One example of the way in which LRS programs have begun to use technology to improve services is in the area of resource sharing. As Richard Ernst, president of Northern Virginia Community College, says, community colleges cannot afford the luxury of dusty stacks. Consequently, he says, "We are dependent, and in our opinion appropriately so, on those institutions with larger and more in-depth resources to meet periodic special needs. ${ }^{168}$ The opinion that LRS programs should not maintain exhaustive collections but should rely on other institutions for indepth support is not a radical one among community college presidents or LRS directors. In the future, however, LRS programs must guard against deterioration of local holdings even as they look to meth- 
ods of accessing and developing resourcesharing opportunities. Eileen Dubin and Linda Bigelow point out that LRS programs are "transforming their roles as collection centers into centers for accessing information. ${ }^{\prime 69}$ This activity will become increasingly important as new methods of storage and retrieval are invented and perfected. Networking with other colleges to access little used but important CD-ROMbased indexes will increase. ${ }^{70}$ The success of linking community colleges with dissimilar institutions into multitype networks for resource sharing is likely to encourage continuation of the trend. ${ }^{71}$ In the future, it will be essential for LRS programs to be proactively involved with networks, consortia, and other agencies as means to obtain unowned materials. Automation of LRS programs, especially the creation of local online databases for catalog access and other LRS processes, must be a college priority. This will enable LRS programs to become part of resourcesharing networks.

Resource sharing is just one area in which technology has changed the nature of LRS programs. In the future, other areas in which the application of electronic information technology can improve operations must be developed. A measure of excellence will result when the application of technology to problems results in greater service to students, faculty, and staff.

\section{Service to Nontraditional Students}

Community colleges have a history of serving unique student groups, or what are commonly called nontraditional learners. These students will make up an increasingly larger percentage of student enrollment. A significant number of educationally disadvantaged students are enrolling in community colleges. For example, estimates indicate that over 50 percent of all students entering community colleges read at or below the eighth-grade level. ${ }^{72}$ The increase in adult learners, another nontraditional student group, has prevented the predicted decline in college enrollments from occurring. ${ }^{73}$ Enrollments in distance education programs, in which students typically receive instruc-

\section{"Estimates indicate that over 50 per- cent of all students entering commu- nity colleges read at or below the eighth-grade level."'}

tion via telecommunications technology or through print-based independent study, have increased tremendously as the technology to deliver instruction to remote sites has become more varied and refined. ${ }^{74}$ Colleges are engaged in providing instruction to employees in the workplace and to students still in high school. All of these nontraditional student groups require innovative and planned approaches to service.

Educationally disadvantaged students, in particular, need the attention of LRS programs. Carol Truett has documented the lack of community college LRS programs geared to disadvantaged students. ${ }^{75}$ With its systems of complicated storage and retrieval procedures, the LRS can be a forbidding place to disadvantaged students. Specific programs designed to deal with both the affective and cognitive needs of these students are required if LRS programs are to serve this group of students more effectively. Instruction must be integrated into regular coursework, because these students in particular need to see the relationship between the library assignment and their achievement. The development of an affinity for the LRS in these students can be one of the greatest motivators for academic progress and can introduce them to the resources needed for lifelong learning. ${ }^{76}$

Students enrolled in distance education also need special consideration in the provision of LRS services. Because they are not required to visit a campus or extension site to receive instruction, special information access, identification, and delivery routines must be established to provide them with the educational services they need. With creative and planned effort, students can receive not only print materials, but audiovisual programming (addressable cable TV channels); microcom- 
puter support (circulating microcomputers with dial-access software); and index access (dial access to CD-ROM networks and/or the college's online catalog). Such access areas will be increasingly important in the future as enrollments grow.

\section{Professional Commitment and Liaison}

Excellence requires commitment. LRS leaders and staff must play a more active role in the higher education environment. Attending and participating in library association or educational technology association conferences must be a continuing part of LRS staff life. However, programming should be directed toward educational decision makers as well. For example, LRS programs should be represented in the AACJC annual meetings and on the programs of other meetings that draw community college administrators and teaching faculty. If the potential of LRS programs to serve their colleges with excellence is to be achieved, it will only be because presidents and other instructional administrators understand the difference between high- and low-quality LRS programs and are able to see the benefits of fully developed LRS programs.

Community college faculty and staff have never been required, nor particularly encouraged, to do research. This attitude must change if LRS programs are to achieve excellence in the future. Critical inquiry and thought are necessary to develop conclusions about quality service. The past must be analyzed and the future hypothesized. The direction and shape of LRS programs must be considered critically in order to have a planned and intended future. The questions that face LRS programs need debate and discussion so the profession can flourish. As Terwilliger has said, "We will shape our destiny by describing it."
"The value of research, however, is
not always in sharing the results, but
in the self-education that occurs dur-
ing critical inquiry."

Research does not have to be published in a juried journal to be important. Other means of commuicating with LRS peers include contributed papers and poster sessions at conferences or even the announcement of findings in local college publications. The value of research, however, is not always in sharing the results, but in the self-education that occurs during critical inquiry. By considering new data and rethinking one's assumptions, personal and professional growth takes place. Such growth is essential where excellence is a goal.

\section{CONCLUSION}

There are many other areas that must be considered as part of the LRS future. The qualifications of future LRS directors, the size and type of future collections, the projected need for space as older buildings are outgrown, the escalating costs of providing more relevant resources and technology, the need for appropriate training and education programs for LRS staff, and the local college administrative structure under which LRS programs will exist are all issues that need consideration. The five issues outlined here are intended to encourage and guide LRS thought toward the challenges of the future-a future where excellence is desired and possible. For, although community colleges and their LRS programs are much closer to $\mathrm{Oz}$, myriad challenges and hard work face them along the yellow brick road before they will enjoy the pleasures of the Emerald City.

\section{REFERENCES}

1. Building Communities: A Vision for a New Century (Washington, D.C.: American Assn. of Community and Junior Colleges, 1988.)

2. Ruth J. Person, "The Organization and Administration of Two-Year Learning Resources,' Library Trends 33:445 (Spring 1985); Arthur M. Cohen and Florence B. Brawer, The American Community 
College (San Francisco: Jossey-Bass, 1982).

3. George B. Vaughan, ed., Issues for Community College Leaders in a New Era (San Francisco: JosseyBass, 1983).

4. Cohen and Brawer, The American Community College.

5. Ibid.

6. Vaughan, Issues for Community College Leaders in a New Era.

7. John E. Roueche and George A. Baker, Access and Excellence: The Open-Door College (Washington, D.C.: Community College Pr., 1987).

8. Vaughan, Issues for Community College Leaders in a New Era.

9. Ibid.

10. Ibid.

11. Roueche and Baker, Access and Excellence.

12. Cohen and Brawer, The American Community College.

13. Vaughan, Issues for Community College Leaders in a New Era.

14. Elaine H. El-Khawas and others, Community College Fact Book (New York: Macmillan, 1988).

15. Cohen and Brawer, The American Community College: Roueche and Baker, Access and Excellence.

16. Roueche and Baker, Access and Excellence; Barbara B. Moran, "The Unintended Revolution in Academic Libraries: 1939 to 1989 and Beyond," College \& Research Libraries 50:25-41 (Jan. 1989).

17. Edmund J. Gleazer, "The Stake of the Junior College in Its Library," College \& Research Libraries 26:263-66, 317 (July 1966), p.265.

18. Moran, "The Unintended Revolution in Academic Libraries," p.25-41.

19. David W. Breneman and S. C. Nelson, "The Community College Mission and Patterns of Funding," in Questioning the Community College Role (San Francisco: Jossey-Bass, 1980), p.72-80.

20. Gloria Terwilliger, "Educational Technology in Multicampus Community Colleges: A Decade of Change," in Advances in Instructional Technology (San Francisco: Jossey-Bass, 1986), p.49-58.

21. Cohen and Brawer, The American Community College, p.28.

22. Building Communities, p.6.

23. Ibid., p.7-8.

24. Joleen D. Bock, "From Libraries to Learning Resources: Six Decades of Progress-and Still Changing," Community and Junior College Libraries 3:35-46 (Winter 1984).

25. Mary Alice Webb, "A Study of the Perceptions of the Presidents, Academic Deans and Learning Resources Administrators in the Public Community Colleges in Florida Regarding the 1972 Library Standards, 'Guidelines for Two-Year College Learning Resources Programs,' " (Ph.D. diss., Florida State Univ., 1980).

26. Bock, "From Libraries to Learning Resources," p.37.

27. Gloria Terwilliger, "Forecasting the Future of Community College Learning Resources Centers," Library Trends 33:523-39 (Spring 1985).

28. American Library Association, Association of College and Research Libraries, Committee on Standards, "Standards for Junior College Libraries," College \& Research Library News 20:200-206 (May 1960).

29. Gorman Louis Duffet, "A Study of the Goals and the Goal Formulation Process in the Libraries of Multi-Unit District Community Colleges," (Ph.D. diss., Univ. of Pittsburg, 1976), p.2.

30. Gleazer, "The Stake of the Junior College in Its Library," p.263-66, 317 ,

31. Ibid., p. 266 .

32. Ibid.

33. Ibid.

34. Betty Duvall, "The Role of the Community College Library," Show-Me Libraries 36:26-29 (Nov. 1984).

35. Bob Burton, "The Learning Resource Center: What's in a Name?" Community and Junior College Libraries 3:17-22 (Summer 1985).

36. B. Lamar Johnson, ed. "The Junior College Library" (Report of a Conference Sponsored by the Univ. of California, Los Angeles, July 12-14, 1965).

37. Cohen and Brawer, The American Community College.

38. Person, "The Organization and Administration of Two-Year College Learning Resources," p.448.

39. Ibid., p.441-57.

40. American Library Association, Association of College and Research Libraries, and the Association for Educational Communications and Technology, "Guidelines for Two-Year College Learning Resources Programs," College \& Research Libraries News 33:305-15 (Apr. 1972).

41. James O. Wallace, "Two-Year College Learning Resources Standards," Library Trends 31:21-31 (Summer 1982).

42. Ibid.

43. American Library Association, Association of College and Research Libraries, Statement on Quanti- 
tative Standards for Two-Year College Learning Resources Programs (Chicago: ACRL, 1979); American Library Association, Association of College and Research Libraries, and the Association for Educational Communications and Technology, "Guidelines for Two-Year College Learning Resources Programs (Revised), Part I," College \& Research Libraries News 43:5-10 Jan. 1982; _ , "Guidelines for Two-Year College Learning Resources Programs (Revised), Part II," College \& Research Libraries News 43:45-49 (Feb. 1982).

44. Association for Educational Communications and Technology and the Association of College and Research Libraries Joint Committee, "Standards for Two-Year College Learning Resources Programs: A Draft," College \& Research Libraries News 50:496-505 (June 1989).

45. Peter F. Drucker, Management: Tasks, Responsibilities, and Practices (New York: Harper-Row, 1974).

46. Ibid.

47. Barbara B. Moran, Academic Libraries: The Changing Knowledge Centers of Colleges and Universities, ASHE-ERIC Higher Education Research Report no.8 (Washington, D.C.: Assn. for the Study of Higher Education, 1984), p.iii.

48. Ibid., p.79.

49. Terwilliger, "Educational Technology in Multicampus Community Colleges," p.49-58.

50. Carl D. Cottingham, "Limited Edition: Small Community Colleges Adapt to New Technologies," in Advances in Instructional Technology (San Francisco: Jossey-Bass, 1986).

51. Moran, "The Unintended Revolution in Academic Libraries," p.25-41.

52. Jonathan F. Fanton, "The Academy and the Future: Constancy within Change," College \& Research Libraries News 50:564-70 (July/Aug. 1989).

53. Terwilliger, "Educational Technology in Multicampus Community Colleges," p.49-58.

54. Peggy Holleman, "How Widely Has the Learning Resources Program Concept Been Adopted?" Community and Junior College Libraries 1:8 (Fall 1982).

55. W. Lee Hisle, The Role of Learning Resource Services in Selected Community Colleges (Ph.D. diss., Univ. of Texas at Austin, 1988).

56. ALA, ACRL, and AECT, "Guidelines for Two-Year College Learning Resources Programs," p.305-15.

57. AECT and ACRL Joint Committee, "Standards for Two-Year College Learning Resources Programs: A Draft," p.496-505.

58. Ibid., p.505.

59. Hisle, The Role of Learning Resource Services in Selected Community Colleges.

60. Pend Armistead and David W. Moore, "Community College Instructors' Attitudes toward Learning Resources Centers and Other Support Services," Community/Junior College Quarterly 11:47-56 (Spring 1987).

61. John A. Lanning, "The Library-Faculty Partnership in Curriculum Development," College \& Research Libraries News 49:7-10 (Jan. 1988).

62. Donald Ray, "The Meaningful and the Procedural: Dilemmas of the Community College Library," The Journal of Academic Librarianship 15:147-50 (July 1989), p.149.

63. Mary Sue Ferrell, executive director of the California Library Association, personal communication: notes from workshop speech at Maricopa Community College, 1985.

64. Ray, "The Meaningful and the Procedural," p.150.

65. Ibid.

66. Ferrell, personal communication, 1985.

67. Moran, "The Unintended Revolution in Academic Libraries," p.38.

68. Richard J. Ernst, "The President Views the Campus Library," The Joumal of Academic Librarianship 3:192-99 (Sept. 1977).

69. Eileen Dubin and Linda Bigelow, "Community College Learning Resource Centers at the Crossroads: Illinois, A Case Study," College \& Research Libraries 47:596-603 (November 1986).

70. Bernard Fradkin, dean of learning resources at the College of DuPage, Glen Ellyn, Ill., personal communication, 1989.

71. W. Lee Hisle, "LSCA Title III Grants Awarded," Texas Library Journal 64:116-17 (Winter 1988).

72. Mae Frances Moore, "Library Instruction for Deficient Readers," Community and Junior College Libraries 4:49-53 (Spring 1986).

73. Moran, "The Unintended Revolution in Academic Libraries," p.25-41.

74. Ron G. Brey, "Expanding the Classroom Through Technology: Meeting the Mission of Community Colleges," Community, Technical, and Junior College Journal 58:29-31 (Feb./Mar. 1988).

75. Carol Truett, "Services to Developmental Education Students in the Community College: Does the Library Have a Role?" College \& Research Libraries 44:20-28 (Jan. 1983).

76. Ibid.

77. Gloria Terwilliger, director of learning resources, Northern Virginia Community College, Alexandria Campus, personal communication, 1989. 